Egyptian J. Nutrition and Feeds (2017), 20 (2) Special Issue: 245-253

\title{
PHYSIOLOGICAL EFFECTS OF POST AND PRE BIRTH EARLY AGE HEAT CONDITIONING ON RABBITS KITS
}

\author{
A. Gouda \\ Department of Animal production, Agric. National Research Center, Dokki, Giza, Egypt. \\ Corresponding author: Ahmed Gouda ${ }^{I}$.E-mail black_tiger2167@yahoo.com
}

\section{SUMMARY}

$\mathrm{T}$ This study was conducted to investigate the effect of early life heat conditioning on some physiological parameters in New Zealand White (NZW) rabbits. Animals were divided into four groups with five replicates, in each replicate six kits $(4 \times 5 \times 6)$, the first group kits were taken from litter of control does (control), the second group kits were taken from litter of does were exposed to heat conditioning at day 15 of pregnancy $\left(36 \pm 1^{\circ} \mathrm{C}\right.$ for $\left.6 \mathrm{hrs}\right)$, the third group were taken from litter of control does, and were exposed to early age heat conditioning $\left(36 \pm 1^{\circ} \mathrm{C}\right.$ for $\left.6 \mathrm{hrs}\right)$ after birth and the fourth group were taken from litter of does were exposed to heat conditioning at day 15 of pregnancy $\left(36 \pm 1^{\circ} \mathrm{C}\right.$ for $\left.6 \mathrm{hrs}\right)$ at day 15 of pregnancy and were exposed to early age heat conditioning $\left(36 \pm 1^{\circ} \mathrm{C}\right.$ for $\left.6 \mathrm{hrs}\right)$ after birth. Red blood cells (RBCs), White blood cells (WBCs) and Hemoglobin ( $\mathrm{Hb}$ ) values were greater on rabbits in fourth group than the third and second groups compared with the lowest values in control group. Rectal temperature and the level of Cholesterol and Corticosterone of rabbits in the 16 week of age under hot summer season in the control group were greater than that in other groups. Early age heat conditioning of all treated groups caused significant $(\mathrm{p}<0.05)$ decreased in liver functions (plasma ALT and AST activity) and Kidney functions (urea and creatinine levels). Total antioxidant capacity, Catalase in plasma and Heat shock proteins 70 (HSP70) of all treated groups were higher than in the control group. Body weight and body weight gain at 8,12 and 16 weeks in kits of heat exposure groups than in the control group. In conclusion, early age heat conditioning of rabbits kits post, pre birth or together led to the improvement in post weaning growth and in thermo-tolerance during the summer season in rabbits.

Keywords: Rabbit kits, Heat conditioning, Total antioxidant capacity, Catalase and Heat shock proteins70

\section{INTRODUCTION}

Rabbits are homoeothermic animals and they are very sensitive to high temperatures since they have few functional sweat glands, limiting them ability to eliminate excess body heat when the environmental temperature is high, rabbits are very susceptible to heat stress when the environmental temperature is high (Marai et al., 2002 and Badawy et al., 2010). Heat stress may lead to increased production of transition metal ions, which can make electron donations to oxygen forming superoxide or $\mathrm{H} 2 \mathrm{O} 2$, which is further reduced to an extremely reactive $\mathrm{OH}$ radical causing oxidative stress (Zhao et al., 2006), also, produced Reactive oxygen species (ROS) which resulted in drastic damage to the cell structures; protein, lipids and DNA, and further induce physiological and pathological changes, resulting in poor performance (AbdelKhalek, 2010). In the rabbit, stress associated with exposure to high ambient temperatures decreases growth performance, possibly because of excessive production of ROS that oxidize and destroy cellular biological molecules (Liu et al., 2011). Several strategies have been recommended to ameliorate the negative effects of a high environmental temperature, one of them exposing animals to heat conditioning noticeably ameliorated by heat acclimation (Yalcin et al., 2001), Recently demonstrated that heat acclimation (HA) improves arterial elasticity (Kaldur et al., 2013), which has been shown to be directly linked to oxidative stress and inflammation (Kals et al., 2011). Heat conditioning associated with the synthesis of heat shock proteins (HSP) enhances the animal survival in rats (Villar et al., 1994), as well as the thermo-tolerance under hot condition in rabbits (Abdel-Kafy, 2006). Therefore, the purpose of this study was to investigate the impact of early heat conditioning on some physiological changes in New Zealand White (NZW) rabbits.

The $16^{\text {th }}$ Scientific Conference for Animal Nutrition, Luxor-Aswan, $28^{\text {th }}$ Nov. $-1^{\text {th }}$ Dec., 2017 


\section{MATERIALS AND METHODS}

One hundred and twenty New Zealand White (NZW) rabbit-kits were used in this study. Kits were housed in cages in an open room $4 \times 6 \mathrm{~m}$ with windows representing $30 \%$ of the walls area. The room was equipped with thermometers and humidity measuring equipment. Animals were divided in cages into four groups (each group of 30 kits into five replicates) as follows: 1st group: kits were taken from litter of control does (Control group (C)), 2nd group: kits were taken from litter of does were exposed to heat conditioning at day 15 of pregnancy $\left(36 \pm 1^{\circ} \mathrm{C}\right.$ for $\left.6 \mathrm{hrs}\right)$ using electric heaters at day 15 of pregnancy (Heat conditioning group at pregnancy (HCP)), 3rd group: A number of 30 kits were taken from litter of control does, and were exposed to early age heat conditioning $\left(36 \pm 1^{\circ} \mathrm{C}\right.$ for $6 \mathrm{hrs}$ ) at one day after birth (Heat conditioning group after born (HCB)) and 4th group: kits were taken from litter of does were exposed to heat conditioning at day 15 of pregnancy $\left(36 \pm 1^{\circ} \mathrm{C}\right.$ for $\left.6 \mathrm{hrs}\right)$ using electric heaters at day 15 of pregnancy and were exposed to early age heat conditioning $\left(36 \pm 1^{\circ} \mathrm{C}\right.$ for $6 \mathrm{hrs}$ ) at one day after birth (Heat conditioning group at pregnancy and after born (HCPB)). Cages were equipped with feeding hopers made of galvanized steel and have nipples for automatic drink. Rabbits reread on cages from weaning (4 week of age) until 16 week of age, the range of environmental temperature during this period was from 34$38^{\circ} \mathrm{C}$.Weights of kits were recorded weekly from weaning until the 16 th week of age. At 16 weeks of age under hot ambient temperature $(41 \mathrm{oC})$ five rabbits from each replicates, rectal temperature was measured by digital thermometer and blood samples were collected few fresh drops of blood taken to determine Red blood cells (RBCs), White blood cells (WBCs), blood haemoglobin (Hb) and Hematocrit \% (HCT) as described by Nemi (1986), blood samples after centrifuged at $3000 \mathrm{rpm}$ for $15 \mathrm{~min}$ plasma stored at $-80 \mathrm{oC}$ to determine plasma total proteins $(\mathrm{g} / \mathrm{dl})$ by the method described by Henry (1974), plasma albumin $(\mathrm{g} / \mathrm{dl})$ based on a colorimetric method described by Doumas et al. (1971). Globulin was calculated by subtraction of plasma albumin from plasma total protein, Cholesterol $(\mathrm{mg} / \mathrm{dl})$, Corticosterone $(\mathrm{ng} / \mathrm{ml})$ and total antioxidant capacity (mmol/l) by Koracevic et al. (2001). Urea, creatinine, activity of aspartate (AST) and alanine (ALT) aminotransferases, were estimated by the colorimetric method using commercial kits (Diamond Diagnostic, Egypt). Livers were removed directly from the five rabbits to determine the activity of catalase (U/g) according to Aebi (1984) and mRNA heat shock protein 70 (HSP 70) according to Tizard (1996).

\section{Statistical analysis:}

Statistical analysis for all measured parameters was performed using the general linear model (GLM) produced by the Statistical Analysis Systems Institute (SAS, 2009).

\section{RESULTS AND DISCUSSION}

Hematological data (Figures 1, 2 and 3) revealed that rabbits were exposed to early age heat conditioning pre and before birth had significantly $(\mathrm{p}<0.05)$ increased number of circulating RBCs, WBCs and $\mathrm{Hb}$ concentration followed by the groups were exposed to early age heat conditioning before or after birth compared with the control group, HCT \% showed a different pattern as there was a significantly increased in all treated groups compared with control. With regard to plasma biochemical (Figures 4 and 5) plasma Cholesterol and Corticosterone decreased $(\mathrm{P}<0.05)$ linearly as all early age heat conditioning groups compared with control group. However, plasma total protein and albumin increased $(\mathrm{P}<0.05)$ in all treated groups but there is no differences between the control and the group were exposed to heat conditioning before born in total protein and albumin Liver functions (plasma ALT and AST activity) and Kidney functions (urea and creatinine levels) in different groups are shown in Figures 6 and 7. Early age of heat conditioning of all treated groups caused significant $(\mathrm{p}<0.05)$ decreased in these parameters compared to control animals. Total antioxidant capacity, Catalase (as antioxidative enzyme) activity and heat shock protein 70 (HSP 70) of all treated group was higher than that control group, however, rectal temperature recorded significantly $(\mathrm{P}<0.05)$ lower of all treated groups was higher than that control group under hot condition which are shown in Figures 8, 9, 10 and 11. The body weight and body weight gain of rabbits are 
indicated in Figures 12,13 and 14. The rabbits had similar body weights at the start of the experiment on four week of age (Weaning). The final body weight at 8,12 and 16 weeks of age and weight gain (4 -8 and 4-16 week of age) significant $(\mathrm{P}<0.05)$ increased by heat conditioning groups compared with control group, there is no differences between body weight at 12 and 16 weeks of age in heat conditioning group at pregnancy (HCP) and heat conditioning group after born (HCB).

All groups subjected to early age of heat conditioning before or after birth and together improved in all parameters that were studied in this experiment, these results indicate that heat conditioning used in the current experiment may have acted as an anti-stressor and diminished the neuropathological influence of heat stress Heat conditioning rabbit's may be due either to ability of animals to prevent the negative effect of heat stress or to the failure of the physiological mechanisms of animals to balance the excessive heat load caused by exposure to high ambient temperature, early age of heat conditioning used as a heat acclimation by influence the activity of a number of dehydrogenases and oxygenases (Habeeb et al., 1993, Ahmed Nagwa, 2000, Ahmed Nagwa et al., 2005 and Fadila and Amal, 2015). Hematological changes seem to play an important role in adjusting the rabbit's physiology during elevated heat stress conditions by improving on RBCs, WBCs, Hb concentration and HCT \%, this improvement can be due to the rabbits adaptation to hot conditions and reducing the oxygen up take and reduces metabolic heat production in a cellular level as counter act to heat load (Marai et al. 1994 and El-Kholy 2003). When animals exposed to heat stress plasma protein, albumin and globulin were decreased, such decline may be due to a decrease in feed utilization and, consequently, to a decrease in protein and fat bio synthesis (Habeeb et al., 1993 and Marai et al. 1999). However, the improvement on plasma protein, albumin and globulin affected by all treatments compared with the control is due to the positive impact early age heat conditioning in enhancing nutrients utilization and heat tolerance (Toghyani et al., 2008 and El-Wardany et al., 2012). Cholesterol concentration also decreases markedly with exposure heat conditioning (Marai et al., 1995; Habeeb et al., 1996). Abdel-Samee (1998) confirmed that exposure of farm animals to heat conditioning in accompanied by a decrease in cholesterol concentration. The decline in cholesterol concentration may be due to the increase in total body water or to the decrease in acetate concentration which is the main precursor for the synthesis of cholesterol (Habeeb et al., 1992; Marai and Habeeb, 1998). The increase in corticosterone level resulted in rabbits more adapted and with better thermo-tolerance under heat stress conditions which used as a stress indicator (Hannela et al. 1990), the treatments in this experiment Blood ALT and AST are biomarkers in the diagnosis of hepatic damage because they are released into the circulation after cellular damage (Naik and Panda, 2007). The acclimation followed by heat stress caused significant $(\mathrm{P}<0.05)$ decreased in enzymes of the liver (ALT and AST levels) and this means that heat acclimation had protective effect against the heat stress, these elevated liver enzyme activities may indicate hepatocellular damage (Mostafa, et al., 2007). These results are in agreement with those of previous studies in rabbit (Fadila and Amal, 2015). Also the results revealed that the heat conditioning was more effective in improving the negative effects of heat stress conditions, as a measure of kidney function status, urea and creatinine are often regarded as reliable markers, thus, elevations in the serum concentrations of these markers are indicative of renal injury simply because the kidneys excrete them, elevation in urea and creatinine in agreement with results of previous studies of (Gudev et al., 2010 and Fadila and Amal, 2015) who suggested that increasing plasma urea level in heat stressed buffaloes closely related with the dynamic of cortisol and blood volume fluctuation in animals under heat stress. The reduction of the rectal temperature in all heat conditioning groups may be due to the fact that rabbits were able to maintain constant rectal temperature during heat exposure by low metabolic rate when previously acclimated to high temperature and in more adaptive rabbits due to more thermo-tolerance during hot condition (Abdel-Kafy et al., 2008). Total antioxidant capacity all heat conditioning groups were significantly higher than control group, the partial resistance to hyperthermia was correlated to the higher antioxidative capacity of the apoptosis cells as reported by Dörthe et al. (2000) and Abdel-Kafy et al., (2008). Catalase enzyme as an antioxidative enzyme was induced for protecting the whole-body against ischemia and reperfusion injury caused by hyperthermia (Yamashita et al., 1998). Catalase activities of all heat conditioning groups were higher than control group, these results were in agrees with previous works reported by Abdel-Kafy et al., (2008) and Fadila and Amal, (2015). mRNA HSP 70 levels in all heat conditioning groups were higher than control group, this may be attributed to estradiol level, has been shown to regulate mRNA levels of HSP 70 (Rivera-Gonzalez et al., 1998 and Tang et al., 1995) and the heat shock transcription factor-I HSF-I (Yang et al., 1995), which is involved in transcriptional regulation of HSP 70 gene expression (Morimoto et al., 1992) Significant improvements in the physiological parameters in this study reflected positively on the 
growth rate and body weight. It was observed that thermal treatment thermally recorded the best growth under hot stress condition and the possibility of early age of heat conditioning in all treatment led to change the temperature of the beginning of the suffering of the effect of heat stress Similar results were found by Abdel-Kafy (2006) and Abdel-Kafy et al., (2008), they reported that rabbit weights were subjected to heat conditioning were higher than in control.

Finally, here we show that early heat conditioning systems have improved heat-tolerance of growing rabbits to heat stress conditions and improved performance. Further research on the effects of heat conditioning we help usrecognize the development of the nervous system of developing rabbits and understand thermal stress more clearly.

Figure 1: Red blood cells (RBCs), White blood cells (WBCs) as affected by early age heat conditioning in NZW rabbits at 16 week of age

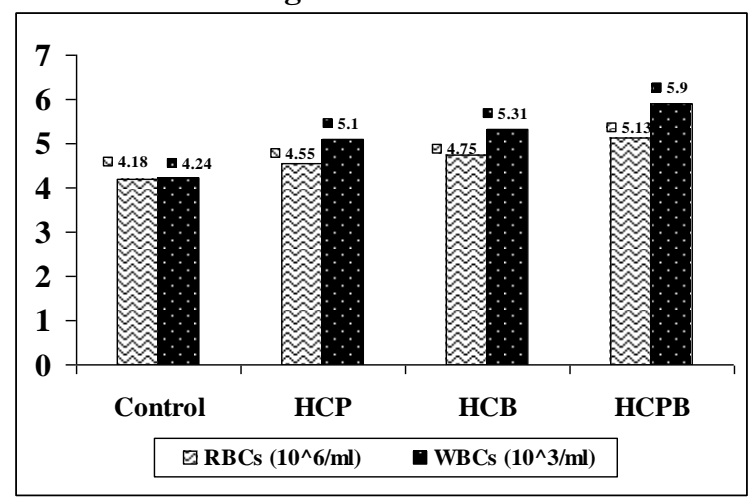

Figure 3: Hematocrit \% (HCT) as affected by early age heat conditioning in NZW rabbits at 16 week of age

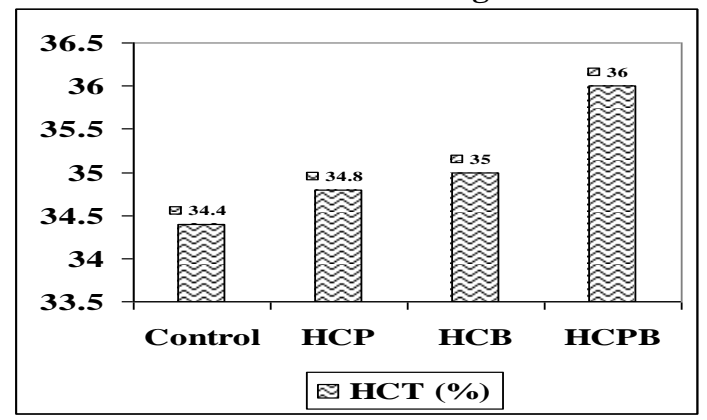

Figure 2: blood haemoglobin $(\mathrm{Hb})$ as affected by early age heat conditioning in NZW rabbits at 16 week of age

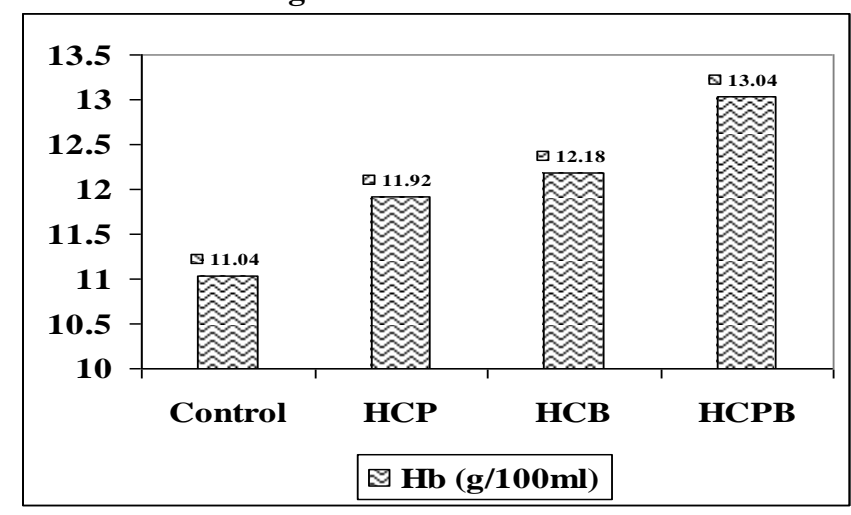

Figure 4: Cholesterol (mg/dl) and Corticosterone (ng/ml) as affected by early age heat conditioning in NZW rabbits at 16 week of age

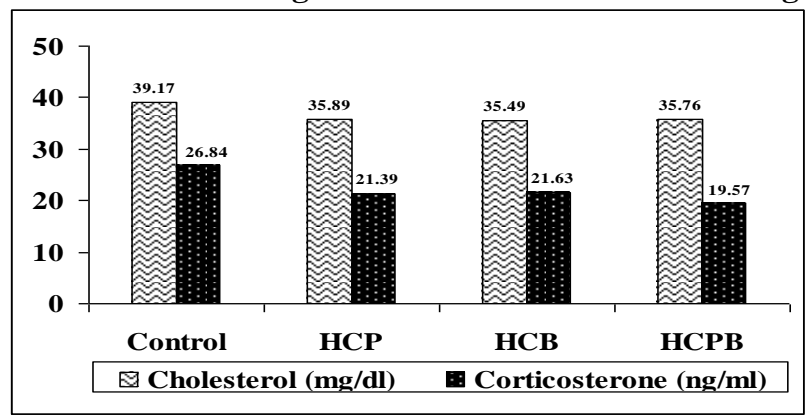


Figure 5: Total protein (g/dl), Albumin (g/dl) and Globulin (g/dl) as affected by early age heat conditioning in NZW rabbits at 16 week of age

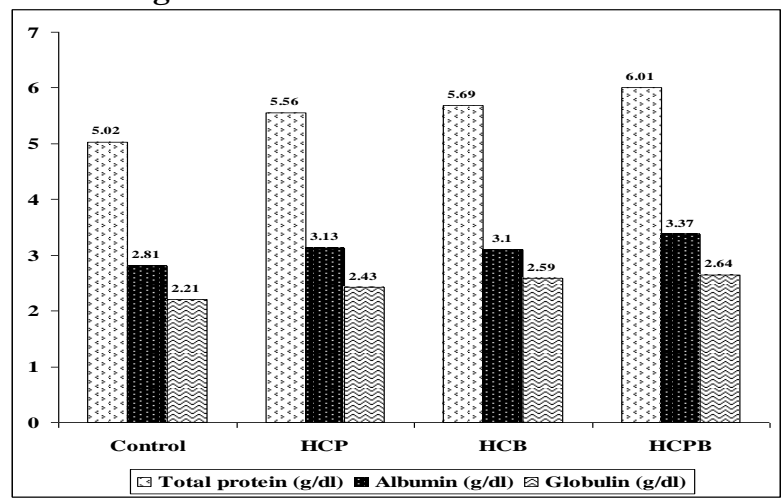

Figure 7: kidney function as affected by early age heat conditioning in NZW rabbits at 16 week of age

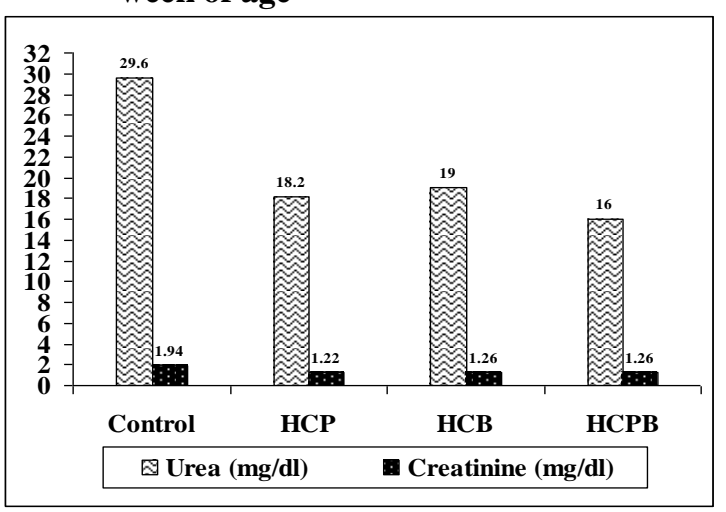

Figure 9: Antioxidant capacity (mmol/l) as affected by early age heat conditioning in NZW rabbits at 16 week of age

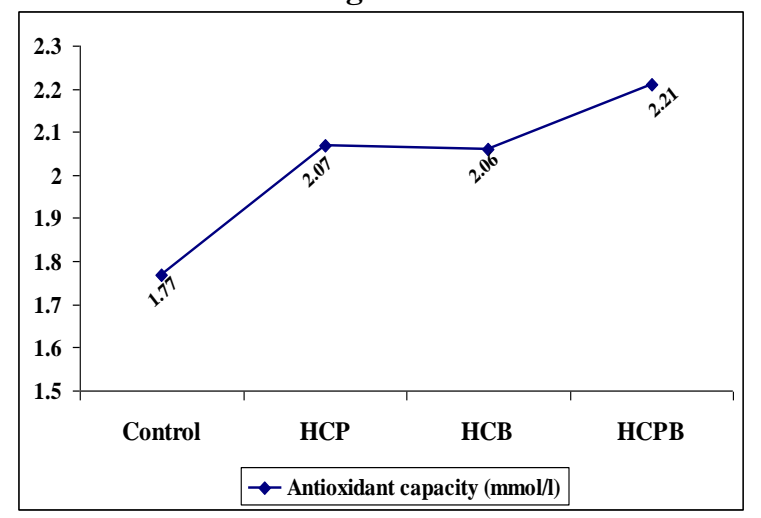

Figure 6: Liver function as affected by early age heat conditioning in NZW rabbits at 16 week of age

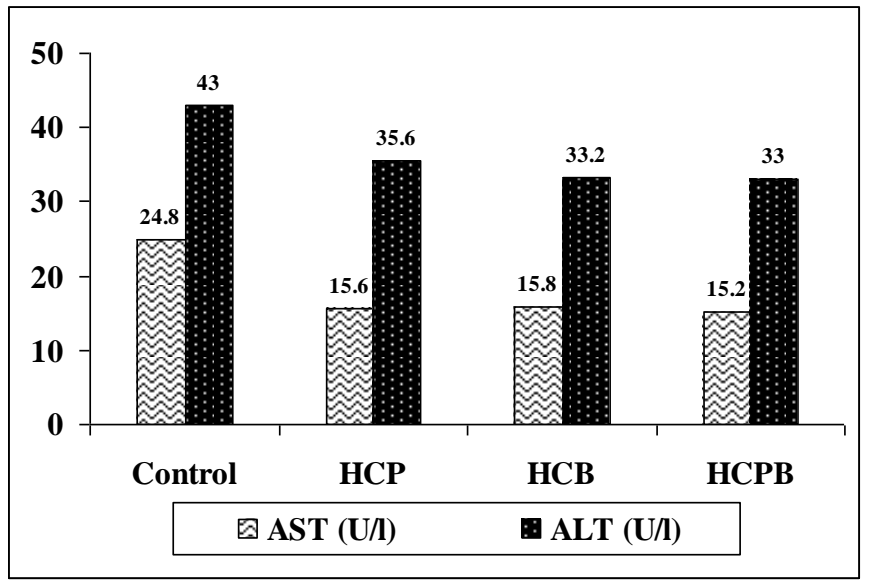

Figure 8: Rectal temperature ${ }^{\circ} \mathrm{C}$ as affected by early age heat conditioning in NZW rabbits at 16 week of age

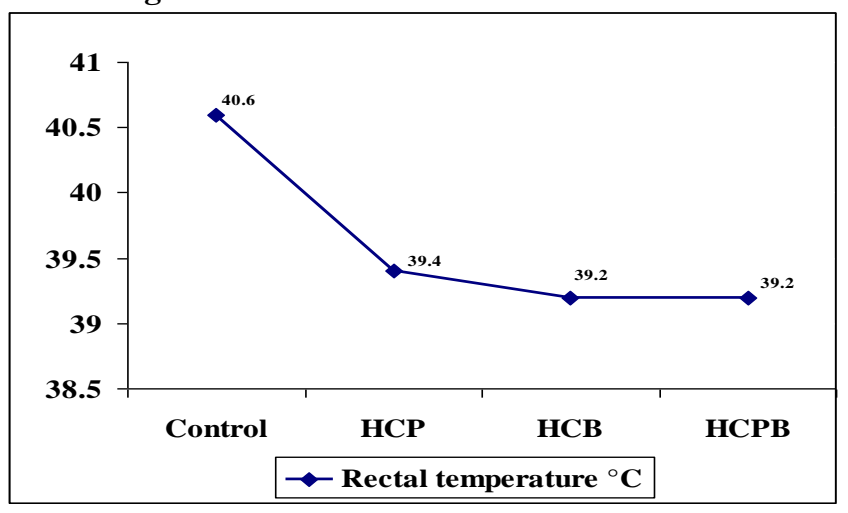

Figure 10: Catalase (U/I) as affected by early age heat conditioning in NZW rabbits at 16 week of age

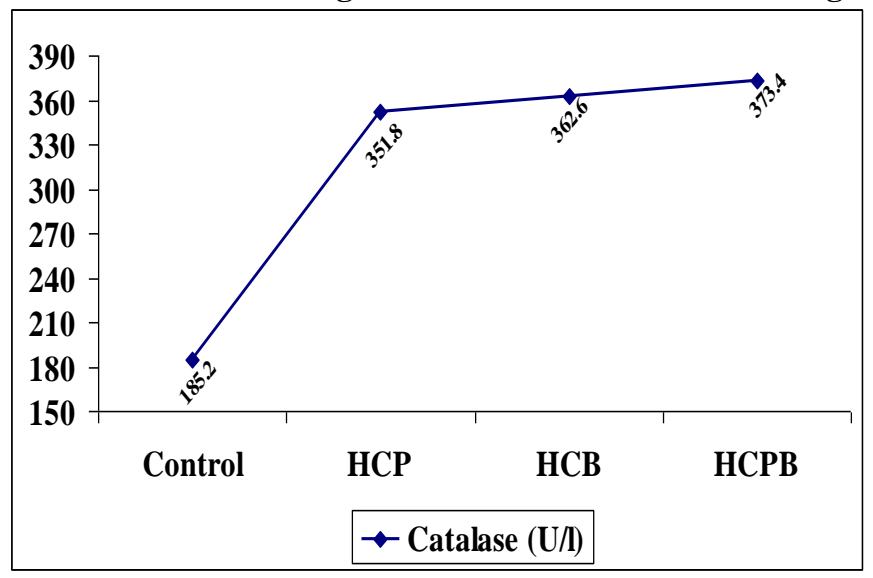


Figure 11: mRNA HSP70 (mg) as affected by early age heat conditioning in NZW rabbits at 16 week of age

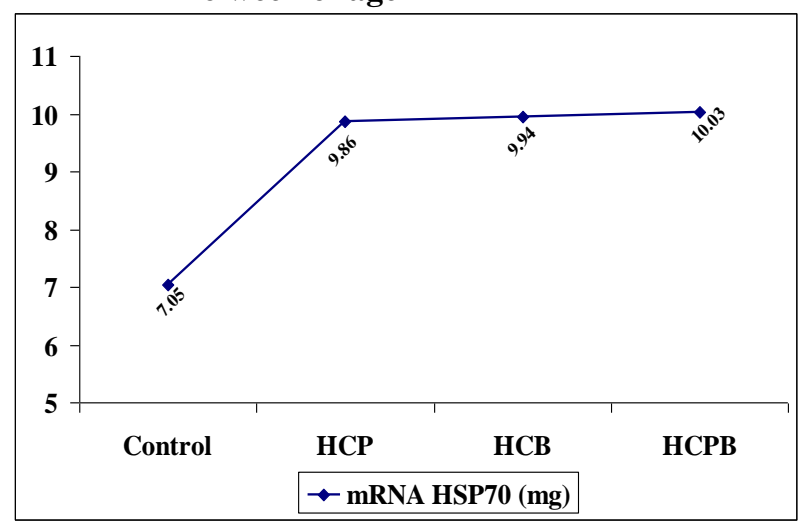

Figure 13: Body weight (g) as affected by early age heat conditioning in NZW rabbits at 12 and 16 weeks of age

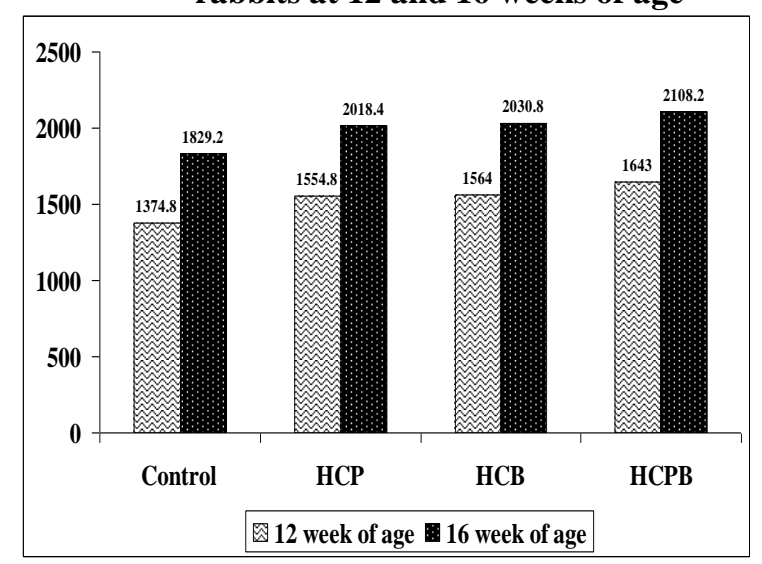

Figure 12: Body weight as affected by early age heat conditioning in NZW rabbits at 4 and 8 weeks of age

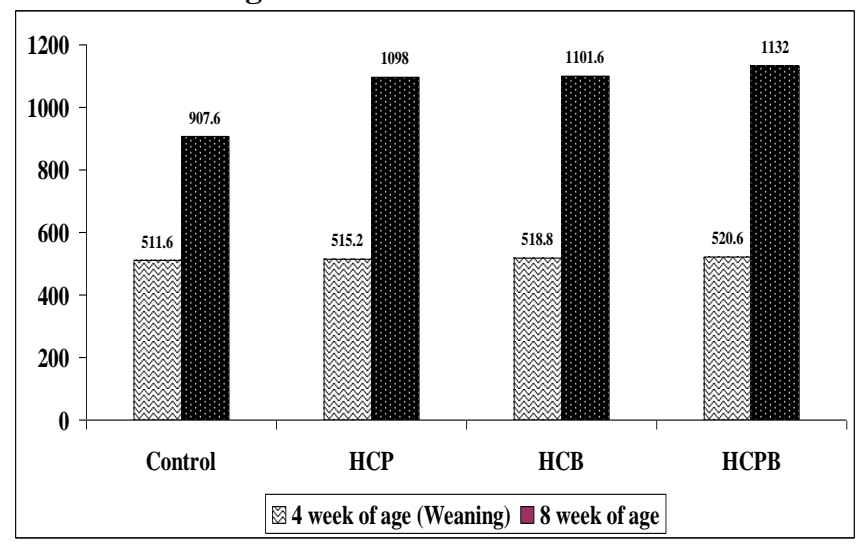

Figure 14: Body weight gain (g) as affected by early age heat conditioning in NZW rabbits at 4-8 and 4-16 weeks of age

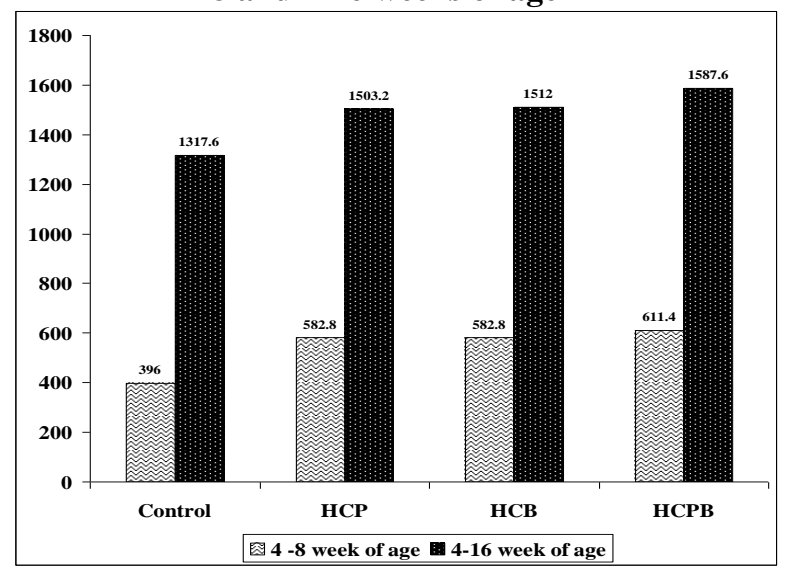

\section{REFERENCES}

Abdel-Kafy E.M. 2006. Effect of heat exposure and feed restriction as bio-stimulation method for enhancing rabbit productivity. Ph.D. Thesis, Agric. Univ., Giza, Egypt.

Abdel-kafy, E. M.; Ali, W A. H.; Hoda, A. S. and Azoz, A. A. A. 2008. Effect of short heat exposure, balanced feed restriction and acetic acid supplement at post weaning on growth and thermoregulation in growing rabbits during hot season. 9th world rabbit congress, june 10-13, verona - italy.

Abdel-Khalek, A. M. 2010. Antioxidants in rabbit nutrition: A review. In Proc.: 6th Int. Conf. on Rabbit Production in Hot Climates, Egypt, 117-138.

Abdel-Samee, A.M., 1998. Improving productivity of heat stressed farm animals using different techniques. In: Proceedings of the International Conference on Animal Production and Health in Semi-Arid Areas, El-Arish, North Sinai, Egypt, pp. 111-126.

Aebi, H. 1984. Catalase in vitro. Methods Enzymol., 105, 121-126. 
Ahmed , A. Nagwa, 2000. Durinal seasonal variations in thermoregulation and physiological reaction of pregnant and nonpregnant rabbits. J. Agric. Sci. Mansoura Univ. 25(6) 3221-33.

Ahmed, Nagwa, Ismail A. M., and Abdel-Kafy, E. M. 2005. Effect of heat exposure and feed restriction on performance of pregnant rabbit-does with emphasis on heat shock protein detection. The $2^{\text {nd }}$ Inter. Conf. Vet. Res. Div. NRC Cairo, Egypt, 27-37.

Badawi 1., Y.K.; M.A. El-Sawy and T.S.T. Seleem, 2010. The impact of exposing semen and doe rabbits to heat stress on heat tolerance of their offspring. The 6th Inter. Con .on Rabbit Prod. In Hot Clim., Assuit, Egypt, 427 - 441.

Dörthe M., S. Katschinski, B. Kristina, Schindler, G. Susann, and F. Joachim. 2000. Pivotal role of reactive oxygen species as intracellular mediators of hyperthermia-induced apoptosis. J. Biol. Chem., 275, 21094-21098.

Doumas, B.T.; W. A. Warson and N. G. Biggs, 1971. Albumin standards and the measurement of serum albumin with bromcresol green. Clin. Chem. Acta., 31:87-96.

El-Kholy, K., H.,(2003).Amelioration of heat stress on rabbits. Ph.D. Thesis Fac. Agric., Cairo Univ. Egypt.

El-Wardany I.; M.M.A. El-Moniary; A.A. Hemid; A.E. Gehad and A. Gouda. 2012. The effect of early age heat conditioning and some feeding programs for heat-stressed broiler chicks on: 2. physiological responses immunological response. Egyptian J. Nut. and Feeds (2012), 15 (1) Special Issue.

Fadila, M. Easa and Amal, M. Hekal 2015. Effect of early heat exposure on some physiological and histological changes in the liver and kidney of rabbits before weaning. Egypt. Poult. Sci. Vol (35) (I): (149-175).

Gudev, D., S. Popova-Ralcheva., P. Moneva., Y. Aleksiev., T. Peeva., Y. Ilieva, and P. Penchev. 2010. Effect of heat-stress on some physiological and biochemical parameters in buffaloes. Italian J. Anim. Sci., 6 (2): 1325-1328.

Habeeb A.A., A.I. Aboul-Naga, H.M. Yousef, 1993. Influence of exposure to high temperature on daily gain, feed efficiency and blood components of growing male Californian rabbits. Egyptian Journal of Rabbit Science 3, 73-80.

Habeeb A.A., I.F.M. Marai, T.H. Kamal 1992. Heat stress. In: Philips, C., Piggins, D. (eds.): Farm Animals and the Environment. CAB International, Wallingford, UK. 27-47.

Habeeb A.A.M., K.A. El-Masry, A.I. Aboulnaga, T.H. Kamal. 1996. The effect of hot summer climate and level of milk yield on blood biochemistry and circulating thyroid and progesterone hormones in Friesian cows. Arab Journal of Nuclear Sciences and Applications 29, 161-173.

Hannela R., A. Hollmen, P. Huttunen and J. Hirvonen 1990. Plasma catecholamine, corticosterone, glucose and fatty acids concentrations and mean arterial pressure and body temperature in haemorrhagic hypovolaemia, hypothermia and combination of these in the rabbit. Acta Physiol. Scand. 139(3): 4419.

Henry, R. J., 1974. Clinical Chemistry: Principles and Techniques. New York, NY: Harper and Row.

Kaldur, T.; J. Kals and V. Ööpik (2013). Heat acclimation increases arterial elasticity in young men. Applied Physiology, Nutrition, and Metabolism, vol. 38, pp. 922-927.

Kals, J.; M. Zagura and M. Serg 2011. $\beta 2$-microglobulin, a novel biomarker of peripheral arterial disease, independently predicts aortic stiffness in these patients. Scandinavian Journal of Clinical and Laboratory Investigation, vol. 71, no. 4, pp. 257-263.

Koracevic D., Koracevic G., Djordjevic V., Andrejevic S., Cosic V. 2001. Method for the measurement of antioxidant activity in human fluids. J. Clin. Pathol., 54, 356-361.

Liu H., Dong X., Tong J., Zhang Q. 2011. A comparative study of growth performance and antioxidant status of rabbits when fed with or without chestnut tannins under high ambient temperature. Animal Feed Sci. and Techno., 164, 89-95.

Marai I.F.M., A.A.M. Habeeb, A.H. Daader, H.M. Yousef. 1995. Effect of Egyptian subtropical conditions and the heat stress alleviation techniques of water spray and diaphoretics on thegrowth and physiological functions of Friesian calves. Journal of Arid Environments 30, 219-225. 


\section{Gouda}

Marai I.F.M., Habeeb A.A.M. 1998. Adaptation of Bos taurus cattle under hot climate conditions. Annals of Arid Zone 37, 253-281.

Marai I.F.M., M.S. Ayyat, H.A. Gabr, U.M. Abd El-Monem 1999. Growth performance, some blood metabolites and carcass traits of New Zealand White broiler male rabbits as affected by heat stress and its alleviation, under Egyptian conditions. Options Mediterraneennes 41, 35-42.

Marai, I. F. M., A. A. M. Habeeb, G. A. El-Sayed and M. Z. Nessem 1994. Growth performance and physiological response of New Zealand White and Californian rabbit under hot summer conditions of Egypt. $1^{\text {st }}$ Int. Conf. Rabbit Prod. In Hot Climates, 6-8 September, 1994, Cairo, Egypt, pp. 619-625.]

Marai, I.F.M., Habeeb, A.A.M., Gad, A.E., 2002. Rabbits' productive, reproductive and physiological performance traits as affected by heat stress: A review Livest. Prod. Sci. 78, 71-90.

Morimoto, R. I., K. D. Sarge and K.A. Aravaya. 1992. transcriptional regulation of heat shock genes . J Biol Chem.267,21987-90.

Mostafa S. I, M. F. F, Bayomy and N. A. R. M. Zahran 2007. The immediate and late effect of sublethal hyperthermia on some biochemical and histological changes in rabbits. J. Egypt Ger Soc Zool; 52(A):29-48.

Naik S. R. and V. S. Panda 2007. Antioxidant and hepatoprotective effects of Ginkgo biloba phytosomes in carbon tetrachloride-induced liver injury in rodents. Liver Int; 27:393-399.

Nemi, C.J. 1986. Schalm's veterinary hematology .Lea and Fibiger, Philadelphia

Rivera-Gonzalez, R., D. N. Petersen, G. Tkalcevic , D. D. Thompson, and T.A. Brown. 1998. Estrogeninduced genes in the uterus of overiectomized their regulation by droloxifene and tamoxifen. J. Sterois Biochem. Mol.Biol.64,13-24.

SAS Institute. (1999). SAS User's Guide. Version 8.02 ed. SAS Institute Inc., Cary, NC.

Tang, P. Z., M. J. Gannon, A. Andrew and D. Miller. 1995. Evidence for estrogenic regulation of heat shock protein expression in human endometrium and steroid-responsive cell lines. Eur. J. Endocrinol. 133,598-605.

Tizard, I. 1996. An introduction in veterinary immunology $4^{\text {th }}$ edition Philadelphia, USA.

Toghyani, M.; A. Khodami, and A.A. Gheisari. 2008. Effect of organic and inorganic chromium supplementation on meat quality of heat-stressed broiler chicks. American J. of Anim. and Vet. Sci. 3 (2): 62-67.

Villar J., Ribeiro S.P., Mullen J.B., Kuliszewski M., Post M., Slutsky A.S. 1994. Induction of the heat shock response reduces mortality rate and organ damage in a sepsis-induced acute lung injury model. Crit. Care Med., 22, 914-21.

Yalcin S, Ozkan S, Turkmut L, Siegel P.B. 2001. Responses to heat stress in commercial and local broiler stocks. 1. Performance traits. Br. Poult. Sci., 42: 149-152.

Yamashita, N., S. Hoshida, N. Taniguchi, T. Kuzuya and M. Hori, 1998. Whole-body hyperthermia provides biphasic cardioprotection against ischemia/reperfusion injury in the rat. Circulation, 98, 141421.

Yang, X., E. C. Dale, J. Diaz and G. Shyamala. 1995. Estrogen dependent expression of heat shock transcription factor: Implications for uterine synthesis of heat shock proteins. J. Steroid Biochem. Mol.Biol.52, 415-19.

Zhao Q-L, Fujiwara Y, Kondo T. 2006. Mechanism of cell death induction by nitroxide and hyperthermia. Free Radic Biol Med, 40: 1131-1143. 


\title{
التاثيرات الفسيولوجيه للتهيئة الحرارية في عمر مبكر قبل وبعد الولاده لصغار الارانب
}

\author{
أحمد جوده عبدالله
}

قسم الاتتاج العيوانسي ، شعبة البحوث الزراعية والبيولوجية ، المركز القومي للبحوث، الدقي ، الجيزه، مصر.

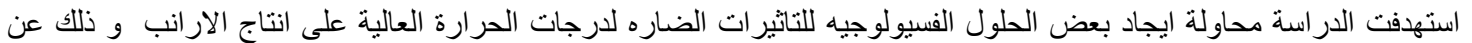

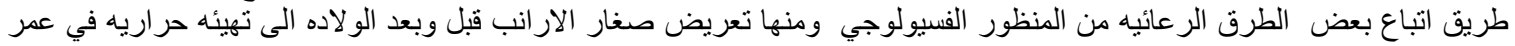

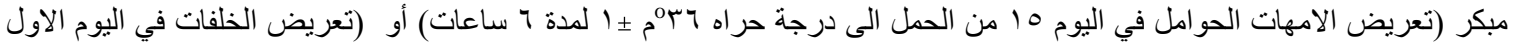

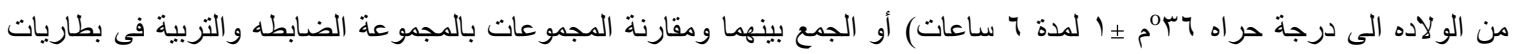

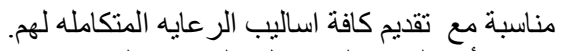

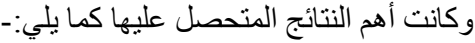

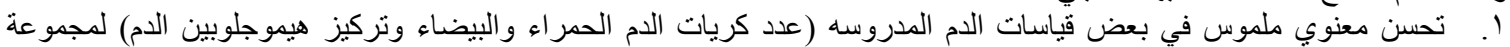

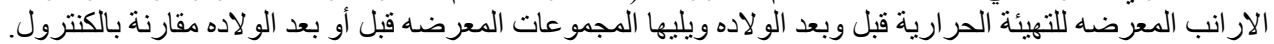

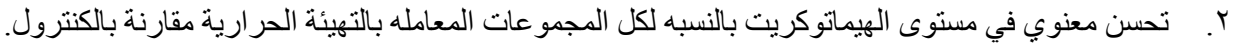

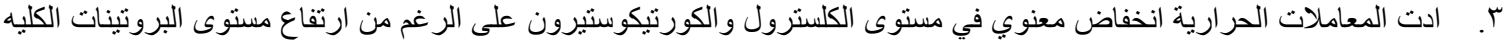

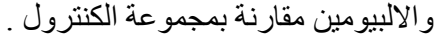

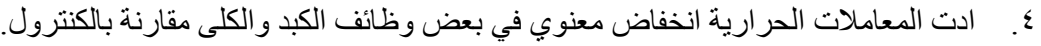

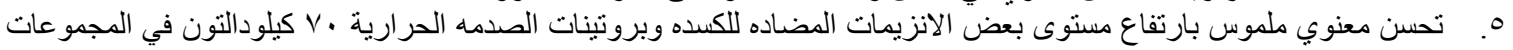

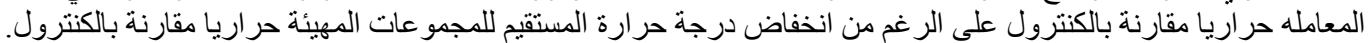

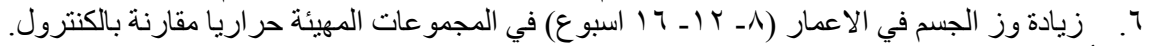

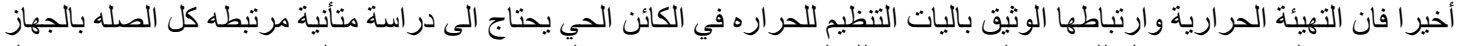

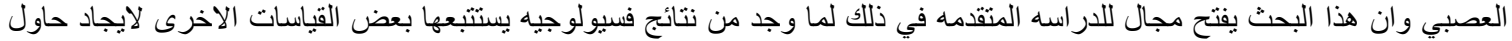

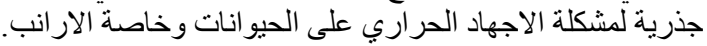

